Revista de
GESTÃOAnal of Integrated
COSTEIRA Integrada COSTAL ZONE MANAGEMENT

\title{
Modelling the thermal effluent of a near coast power plant (Sines, Portugal) ${ }^{*}$
}

\author{
D. V. Salgueiro $;$ H. de Pablo ${ }^{a}$; R. Neves ${ }^{a} ;$ M. Mateus ${ }^{a}$
}

\begin{abstract}
The present work is focused on the dispersion of a thermal effluent, produced by the Sines power plant, Portugal, along coastal waters. This facility intakes a yearly average around $40 \mathrm{~m}^{3} / \mathrm{s}$ of seawater, for the required cooling process, which is subsequently discharged back to the ocean at a $10^{\circ} \mathrm{C}$ increase in temperature. A three-dimensional hydrodynamic local model was nested into a regional model and set up to simulate the transport of the thermal effluent during two distinct periods, August and October 2013, respectively featuring dominant north and south wind. The simulations were performed for both situations, with and without the thermal discharge, where the later provides baseline scenarios. Obtained model results closely followed the existing field data. The temperature increase is shown to decay from $10{ }^{\circ} \mathrm{C}$ near the outlet vicinity to $2{ }^{\circ} \mathrm{C}$ at a distance of $2 \mathrm{~km}$ from the outlet for both scenarios. Even though the main driving force of this phenomenon is the wind, tidal conditions also have additional influence on thermal plume dispersion near the discharge area. In the north wind scenario the plume extends away from the coast while under south wind dominance the plume is contained near the coast, extending towards the inlet. As a consequence there is a positive feedback under south wind dominance, which is caused by the intake of already warm water from the thermal plume itself. Consequently, south wind dominance is the most unfavorable scenario for both coastal environment and the operational efficiency of the power plant.
\end{abstract}

Keywords: Thermal discharge; Three-dimensional model; Coastal hydrodynamics; Water temperature

\section{RESUMO}

Modelação de um efluente térmico numa zona costeira (central termoelétrica de Sines, Portugal)

Este artigo tem como objetivo estudar a dispersão do efluente térmico da central termoelétrica de Sines (Portugal) na zona costeira. Esta central retira em média $40 \mathrm{~m}^{3} / \mathrm{s}$ de água do oceano Atlântico que após o processo de refrigeração é restituída à fonte através de dois canais, com uma temperatura de $10^{\circ} \mathrm{C}$ acima daquela que tinha na zona de captação. De modo a estudar o transporte deste efluente térmico foi implementado um modelo hidrodinâmico tridimensional acoplado a um modelo regional. Foram simulados e analisados dois cenários de ventos diferentes, vento predominante do quadrante norte e vento predominante do quadrante sul. Para cada tipo de vento são comparados os resultados para a situação com e sem descarga. Os resultados obtidos com o modelo evidenciam a anomalia térmica, observável nos dados de campo, mostrando um aumento variável entre $10^{\circ} \mathrm{C}$, na região próxima à descarga, até $2^{\circ} \mathrm{C}$ a cerca de $2 \mathrm{~km}$ da mesma área, para ambos cenários. Contudo, enquanto que no cenário de vento norte se observa uma pluma térmica estreita, ao longo da costa, no caso do vento sul observa-se uma pluma mais confinada à região da saída do efluente. O vento sul é o cenário mais desfavorável à eficiência da

(a) Corresponding author to whom correspondence should be addressed.

a MARETEC, Instituto Superior Técnico, Universidade de Lisboa, Av. Rovisco Pais, 1049-001 Lisbon, Portugal.

* Submission: 8 JAN 2015; Peer review: 1 MAR 2015; Revised: 20 MAY 2015; Accepted: 26 JUN 2015; Available on-line: 29 JUN 2015

This article contains supporting information online at http://www.aprh.pt/rgci/pdf/rgci-577_Salgueiro_Supporting-Information.pdf
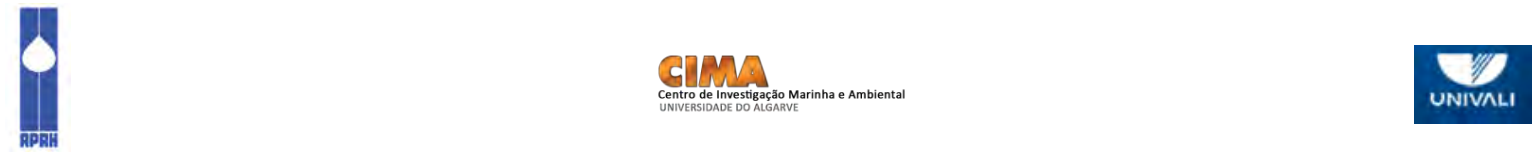
central uma vez que nesta situação a pluma é direcionada para zona de captação. Assim conclui-se que o vento tem um papel preponderante na dispersão do efluente térmico. Os resultados do modelo mostram ainda que a maré também influência a dispersão, sobretudo na zona junto à descarga.

Palavras-Chave: Efluente térmico; Modelo tridimensional; Hidrodinâmica Costeira; Temperatura da água

\section{Introduction}

Coastal areas are often used as a disposal environment for thermal effluents originating from the cooling processes in thermal or nuclear power plants. Studies providing information on thermal effluent behavior in receiving environments can contribute to efficiently manage such discharges, mitigating impacts on relevant environmental and economic values (Abbaspour et al., 2005). The changes caused by the effluents of power plants on ambient water temperature and, consequently, their impact on the aquatic biota has been studied for decades (e.g., Takesue \& Tsuruta, 1978; Kelso \& Milburn, 1979; Hester \& Doyle, 2011; Coulter et al., 2014).

Reported values show that power plants can cause temperature increases that range from $1-2^{\circ} \mathrm{C}$ up to $15^{\circ} \mathrm{C}$, in both rivers and seawater (Takesue \& Tsuruta, 1978; Kelso \& Milburn, 1979; Madden et al., 2013; Stewart et al.,2013; Coulter et al.,2014;). Since temperature is an essential environmental variable, affecting the metabolic rate of organisms and the levels of dissolved oxygen (Langford, 1990; Agarwal, 2005; Coulter et al., 2014), any disturbances in ambient temperature has the potential to disrupt the marine environment (e.g. Martinez-Arroyo et al., 2000; Poornima et al., 2005; Chuang et al., 2009; Choi et al., 2012). Therefore, the forecast of the thermal plume transport and dispersion in the receiving water body is critical to assess its environmental exposure.

There are several methodologies to study thermal plume behavior, ranging from physical models (El-Ghorab, 2013), to in situ data analysis (e.g. Jan et al., 2004; Hunt et al., 2010) to the use of numerical models (e.g. Bedri et al., 2013). The latter option allows the continuous representation of the environmental system in space and time, and with fewer information requirements and reduced resources when compared to the other options (Jones et al., 2007).

A common practice to discharge thermal effluents consists of open channels with free surface flow and along the water column, such as the examples provided by Abdel-Latif et al. (2007) and Fossati et al. (2011). Open channels are more cost effective when compared with submerged point or multiport diffusor systems, although this type of diffusors can provide an increased initial mixing (Kim \& Cho, 2006).

In the open channels systems the effluent is released at lower velocities, originating a buoyant plume, similar to plumes caused by natural geophysical phenomena such as tributaries and rivers. Thermal plumes spread from the outlet depending on transport and mixing mechanisms controlled by environmental conditions, with wind stress acting as a major driving force (Lentz \& Largier, 2006).

This work presents a methodology based on the implementation of a three-dimensional numerical model to study the dynamics of a thermal plume originated by a power plant located at the Portuguese west coast. A reference scenario without the effluent was used to compare with other scenarios where the effluent is present, for simulations with distinct wind conditions. The differences between the reference and the other scenarios were then quantified and discussed, highlighting the less favorable conditions for plume dispersion.

\section{The case study}

The Sines thermal power plant is located on the west Portuguese coast, as shown in Figure 1. This thermal power plant has a total installed capacity of $1192 \mathrm{MW}$. On yearly average, $40 \mathrm{~m}^{3} / \mathrm{s}$ of cooling water go through the intake structure (Direcção de Produção Térmica da EDP, 2012) and, after flowing through the condenser system, are discharged back to the ocean by two open channels, along the water column, which depth is around $4.5 \mathrm{~m}$. The discharge structure is located approximately $400 \mathrm{~m}$ to the south of the water intake.

Coastal hydrodynamics, particularly in what concerns superficial currents and waves, is conditioned by dominant wind patterns. Furthermore, wind is also responsible for the vertical movements caused by upwelling phenomena in this area (Barton, 2001; Santos et al., 2011). During a typical year, $80 \%$ of wind observations exhibit north wind dominance (See Supporting Information I), leading to strong upwelling along the Portuguese west coast (Fiúza, 1983).

\section{Methodology}

MOHID (www.mohid.com), Portuguese acronym for MOdelo HIDrodinâmico [Hydrodynamic Model], is the numerical model applied on this work. This model has been largely applied in several studies for coastal and estuarine systems (Mateus \& Neves, 2008; Vaz et al., 2009; de Pablo et al., 2013; Fossati \& Piedra-Cueva, 2013; Otero-Díaz et al., 2014; Sousa et.al., 2014), having shown its ability to simulate complex systems and processes. 

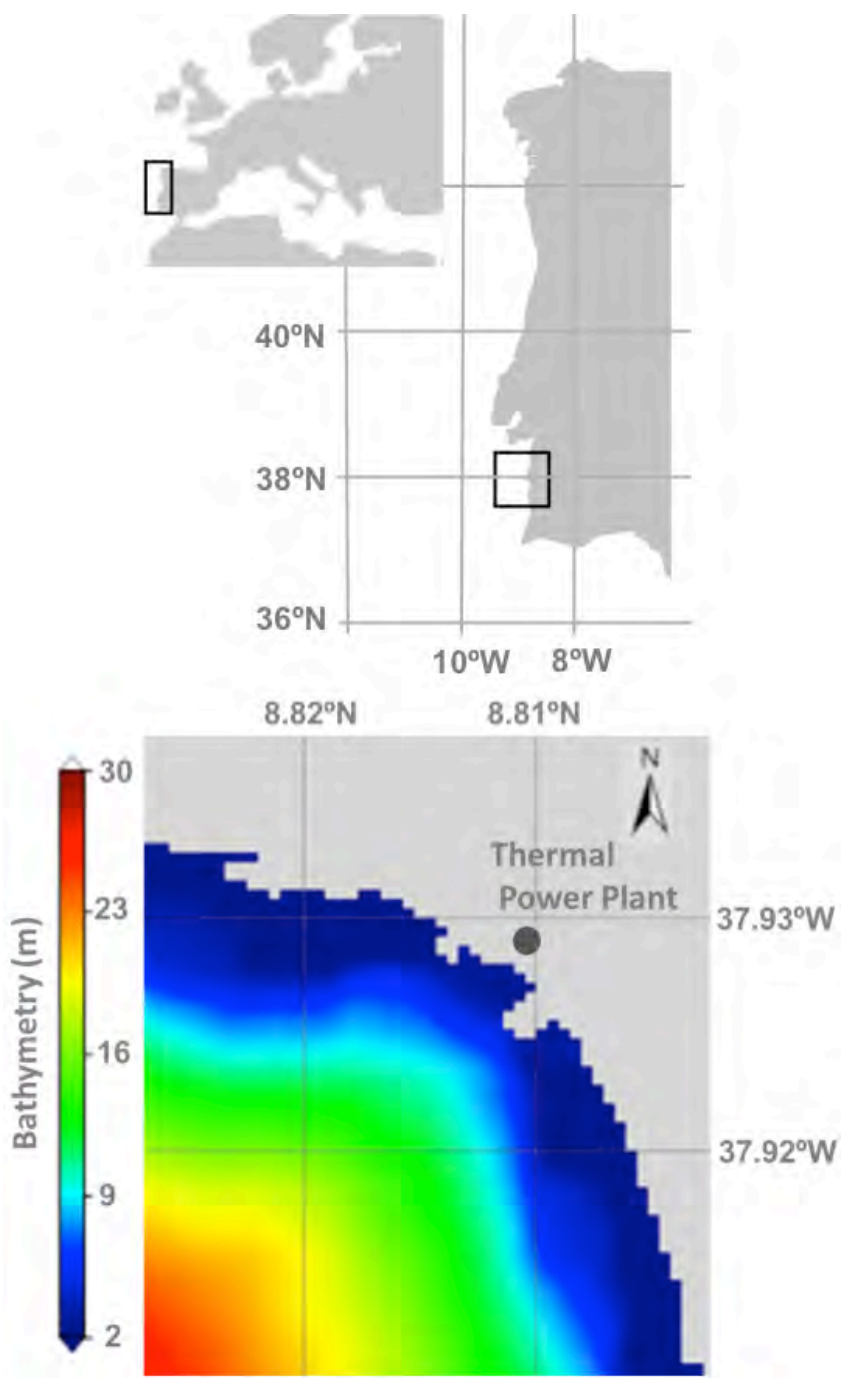

Figure 1 - (a) Location of the study area. (b) Bathymetric data around the around the Sines thermal power plant intake and outlet structures.

Figura 1 - (a) Localização da área de estudo. (b) Batimetria junto à zona de tomada e descarga de água de refrigeração da central termoelétrica de Sines.

MOHID water system solves the three-dimensional incompressible primitive equations, equilibrium, Boussinesq approximation and Reynolds approximation. The governing continuity equations are described in Supporting Information II.

For this work, the horizontal turbulent viscosity is set uniform in each domain. To handle vertical turbulent viscosity MOHID is coupled to the General Ocean Turbulence Model (GOTM, online at http://www. gotm.net), through which the $\mathrm{k}-\varepsilon$ model is parameterized according to Canuto et al. (2001).

The mass-balance equation for temporal and spatial variations of salinity and temperature is expressed in Supporting Information II. The density is solved with the UNESCO state equation as a function of salinity, temperature and pressure (Supporting Information II).

Regarding temporal discretization, MOHID uses semiimplicit algorithms to compute the processes that have higher stability requirements, like vertical advection and diffusion, and explicit methods for processes less constrained to the stability problems, like horizontal transport (Neves, 2013). A more detailed description of the numerical algorithms can be found in Martins et al. (2001).

In this study the numerical model was implemented with a downscaling methodology. Such method is useful to interpolate the boundary conditions of locally refined models from regional, less resolved, models (Ascione et al., 2014). The model was configured using four nested domains as shown in Supporting Information III. The first level (A) has a spatial resolution of $6000 \mathrm{~m}$, the second (B) and third (C) levels have 1200 $\mathrm{m}$ and $240 \mathrm{~m}$, respectively, and the fourth (D) and most refined level is discretized using 48 meter cells. The geographic dataset used for the bathymetries was obtained from the European Marine Observation and Data Network (2014). All the domains were setup in 3D, where a z-level vertical discretization (Martins et al., 2001) was adopted. This way it was possible to implement 7 sigma-type layers on the top for all domains, and a variable number of fixed layers below, according to its bathymetric topology.

The domain A works as an acquisition window, acquiring data from the PCOMS operational model (www.mohid.com/operational), which provides results for tide levels, velocity fields, density, temperature and salinity for the whole Portuguese coast, as described by MOHID water system solves the three-dimensional incompressible primitive equations, assuming Hydrostatic Mateus et al. (2012). Hence PCOMS provides horizontal open boundary conditions for regional models like the present one. Open boundary conditions are then applied through a Flow Relaxation Scheme (FRS) for temperature, salinity and velocities (Martinsen \& Engedahl, 1987) whereas level is radiated through a condition provided by the Flather method (Flather, 1976), both described by Riflet (2010). At the vertical open boundary with the atmosphere the model is forced with atmospheric results, provided by Mesoscale Meteorological Model 5 operational model (MM5, online at $\mathrm{http} / / /$ meteo.ist.utl.pt/), for air temperature, wind intensity and direction, atmospheric pressure, solar radiation and cloud coverage. From this data, the model computes momentum and heat fluxes, allowing for a variable interaction between free surface and atmosphere.

The intake and discharge structures are accurately modelled on the domain $\mathrm{D}$, as well as the nearby port of $\mathrm{Si}$ nes. For the water intake, a constant flow of $40 \mathrm{~m}^{3} / \mathrm{s}$, is considered and modelled by a simple sink, whereas the effluent is modelled by a source term, injecting a $30 \mathrm{~m}^{3} / \mathrm{s}$ local discharge at the downstream section of the open channels and two $5 \mathrm{~m}^{3} / \mathrm{s}$ lateral linear discharges, simulating the crosswise flow percolating through the 
breakwaters. The intake and discharge of water are both made along the water column simulating the real conditions. It was also implemented a bypass function that prescribes a $10^{\circ} \mathrm{C}$ rise in temperature of the discharged water temperature, relative to the intake. This continuous offset value was obtained by applying the heat equation to the turbine generators and cooling system.

\section{Results and discussion}

\subsection{Model validation}

The model setup used in this study was validated at two different domain levels. The regional solution of the model PCOMS, from where the horizontal open boundary conditions were downscaled, was validated with remote sensing data for sea surface temperature (SST) and in situ observations. This is a routine validation described by Mateus et al. (2012). The local higherresolution model, where the thermal discharge was implemented, was validated with in situ observations for water level and sea surface temperature, recorded by a moored buoy located near the Sines port (Instituto Hidrográfico, 2014a, b).

Temperature data acquired during in situ monitoring campaigns, disclosed by the power plant executive board, was also used to validate the higher-resolution model application. These campaigns were conducted directly, by sampling the water column in the vicinity of the discharge and in a location displaced from the area of influence of the thermal plume. Remote sensing data was not used to validate the higher resolution model given the lack of resolution in the images.

Results for water level show a good fit with field data, with a Pearson correlation coefficient of 0.99 (Supporting Information IV). The root mean square error (RMSE), shows a relatively small difference $\left(0.17^{\circ} \mathrm{C}\right)$ between model predictions and field observations for SST, denoting a good fit between model outputs and data (Supporting Information IV).

Nonetheless, the model misses the high frequency fluctuations in the SST recorded by the buoy, as seen in Supporting Information IV. Apparently, the model tends to overestimate superficial temperature, as evidenced by the bias error (BE) (Supporting Information IV). The calculated temperature by the model is an average value for a $48 \times 48$ meters cell ( 1 meter deep), and not a single point matching the location of the buoy, which may explain this outcome. Moreover, the variability recorded by the buoy can be related with it is sensitivity to surface currents and wind, since the float sensor is located right below the water surface.

The model follows the trend of in-depth monitored temperature with significant accuracy. A Pearson correlation coefficient of 0.97 was obtained for both locations, suggesting that the model exhibits a positive variation relative to field data (See Supporting Information IV). The RMSE denotes some overestimation of temperature by the model $\left(\sim+1{ }^{\circ} \mathrm{C}\right)$ in the vicinity of the outlet, and a slight underestimation of the temperature in the reference site $\left(\sim-0.4{ }^{\circ} \mathrm{C}\right)$. The wider difference between modelled and observed data may be related to the assumption made for the discharge; the model relies on a constant yearly average value, ignoring possible variations on the power plant operation during the simulated period.

\subsection{Thermal plume dynamics}

Temperature affects almost every aspect of aquatic life. Hence, thermal effluents from power plants have the potential to cause significant perturbations to the coastal marine environment. There are now mounting evidences of the detrimental impact of thermal stress on the biota (e.g., Young \& Gibson, 1973; Poornima et al., 2006; Arieli et al., 2011; Ingleton \& McMinn, 2012; Jiang et al., 2013), and its combined effect with the chloride used as an antifouling agent in power stations pipes (e.g., Holmes, 1970; Poornima et al., 2005; Saravanan et al., 2008; Chuang et al., 2009).

Considering the harmful effects that the cooling water may have on the costal environment, it is important to understand the magnitude and range of its influence upon discharge. In this context, simulating velocity fields using coastal models is extremely useful to monitor and interpret the dispersion of the warmer plume (Wei et al., 2013). Within this framework, we set up a three-dimensional hydrodynamic and temperature model to simulate the transport of the cooling water under two distinct wind conditions, August and October 2013 featuring dominant north and south winds, respectively, and compared them to the reference scenario.

Surface velocities are usually higher under north wind regimes than under south wind, as seen in Figures 2 and 3 . The presence of the cooling water discharge induces an increase on surface velocity in the vicinity of the outlet, by approximately $0.1 \mathrm{~m} / \mathrm{s}$, in both the north (Figure 2b) and south (Figure 3b) wind scenarios. This is an expected outcome, since the wind pushes the warmer and less dense water discharged in the coastal area.

The effect of the thermal plume on the surface temperature field under north wind and south wind conditions is depicted in Figure 4 and Figure 5, respectively. Also, the anomaly in surface temperature induced by the presence of the plume is illustrated Figures 6 and 7.

A maximum temperature increase of approximately $10^{\circ} \mathrm{C}$ is observed near the outlet, when compared to the baseline simulation (no thermal effluent). Under north wind conditions with an intensity about $5 \mathrm{~m} / \mathrm{s}$, there is 


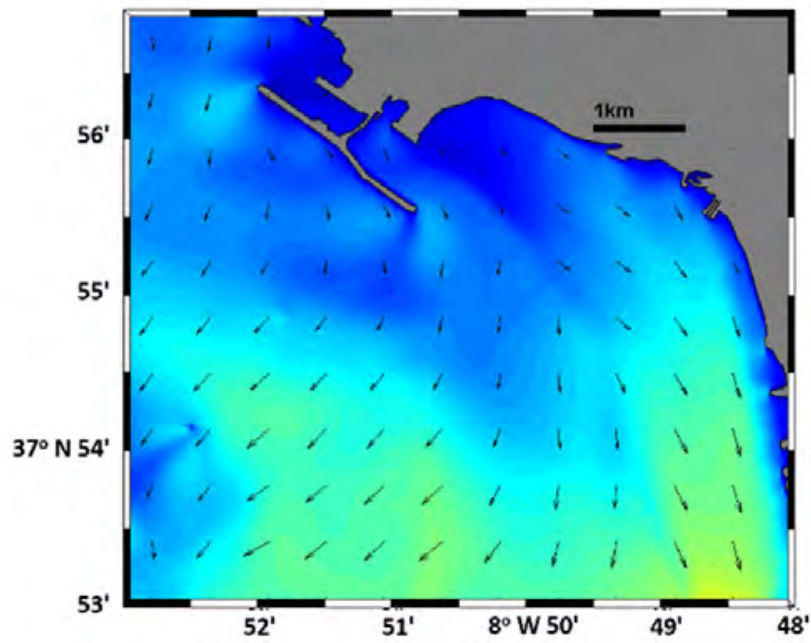

(a)

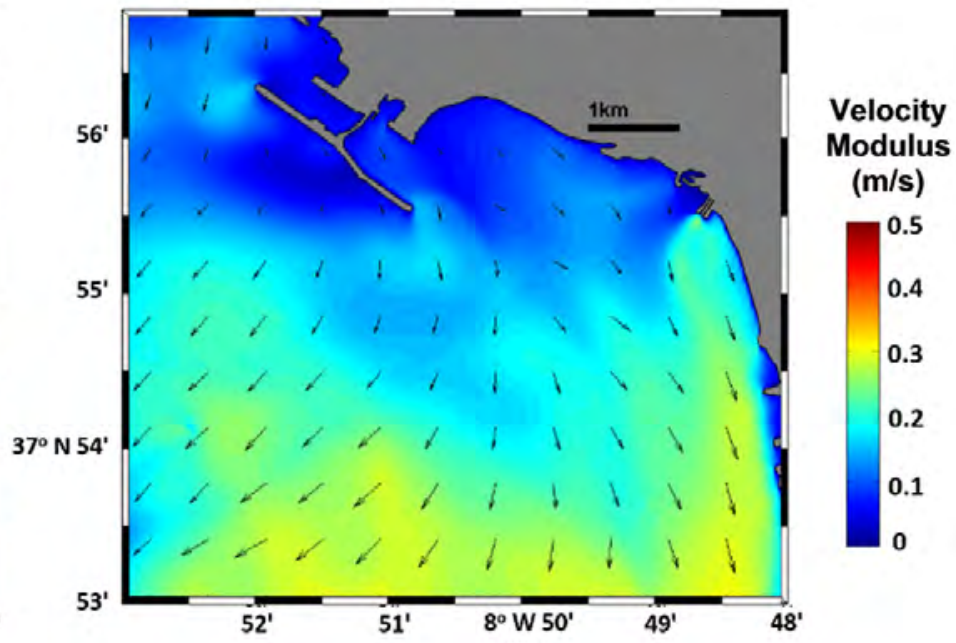

(b)

Figure 2 - Model results for the velocity modulus, without (a) and with (b) discharge, in north wind scenario. Figura 2 - Resultados para o módulo da velocidade, sem (a) e com descarga (b), no cenário de vento norte.

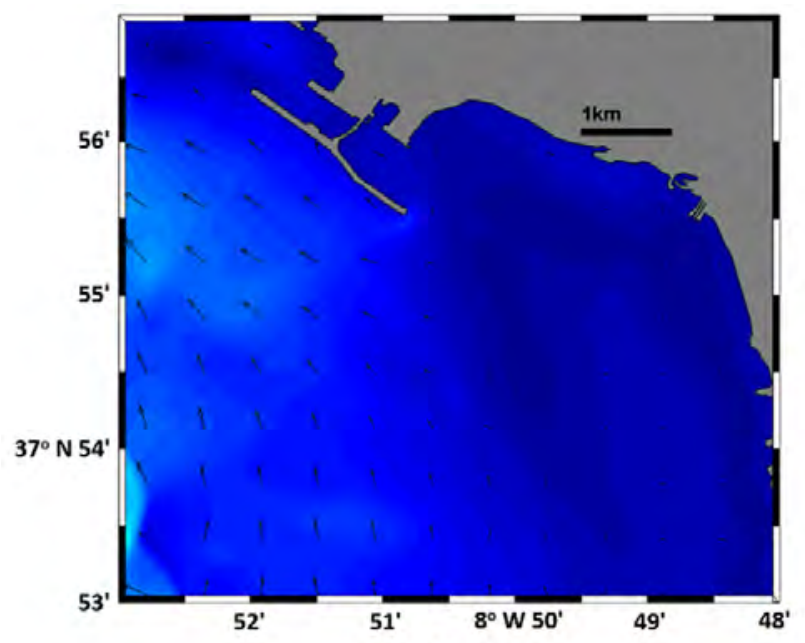

(a)

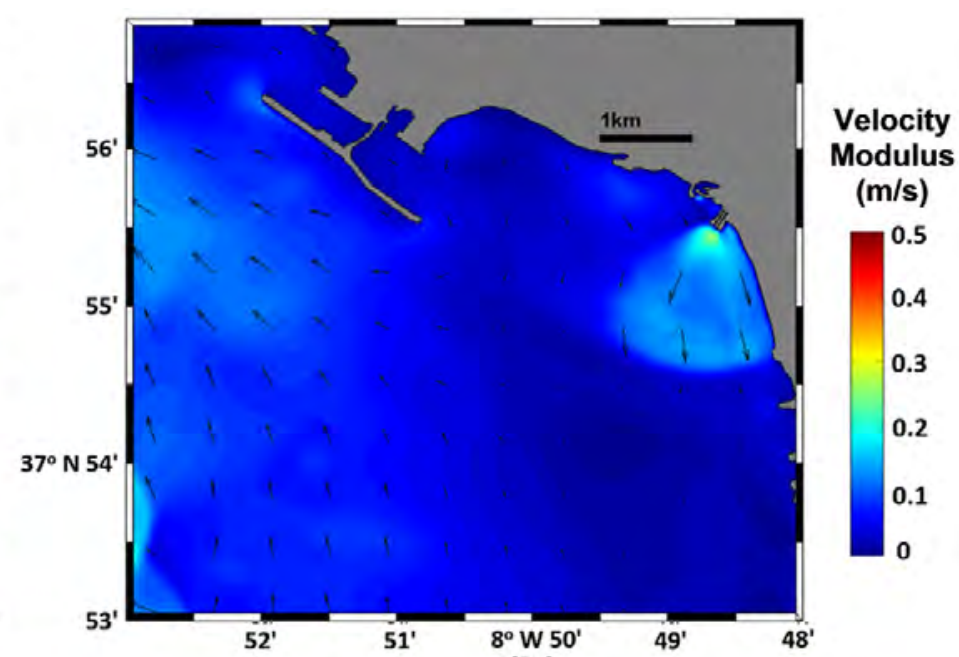

(b)

Figure 3 - Surface velocity, without (a) and with (b) discharge, in south wind scenario.

Figura 3 - Velocidade superficial, sem (a) e com descarga (b), no cenário de vento sul.

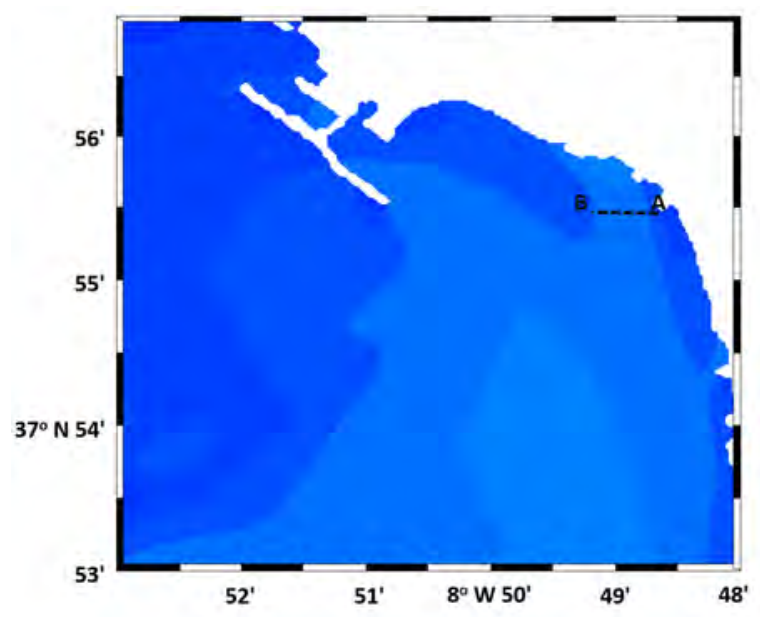

(a)

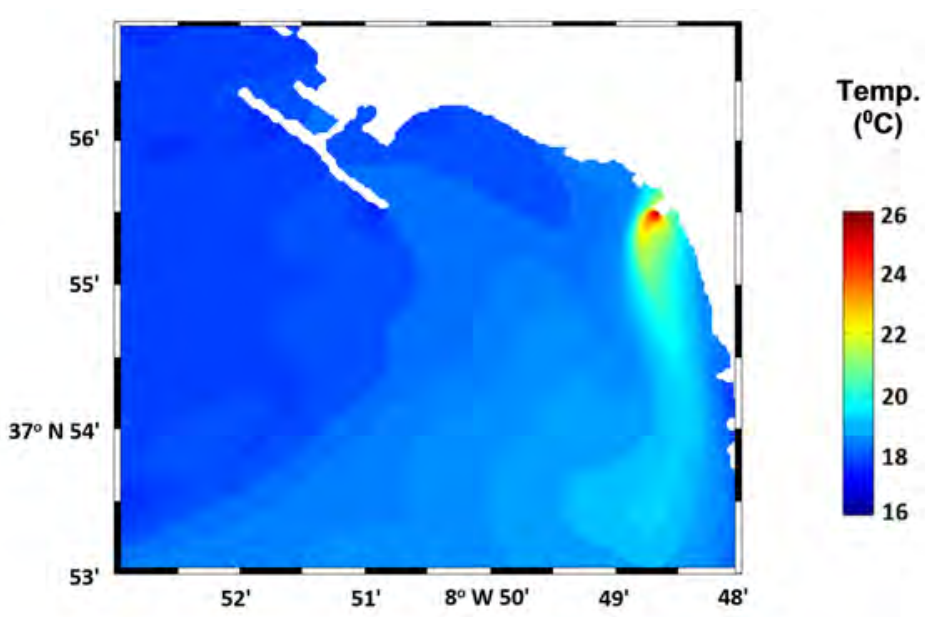

(b)

Figure 4 - Model results for superficial temperature, without (a) and with (b) discharge, in north wind scenario. Figura 4 - Resultados para a temperatura à superfície, sem (a) e com descarga (b), no cenário de vento norte. 


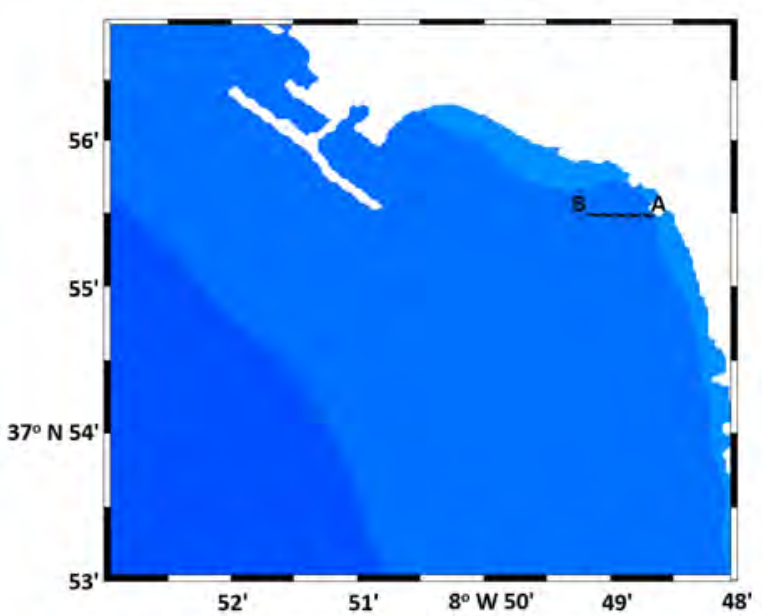

(a)

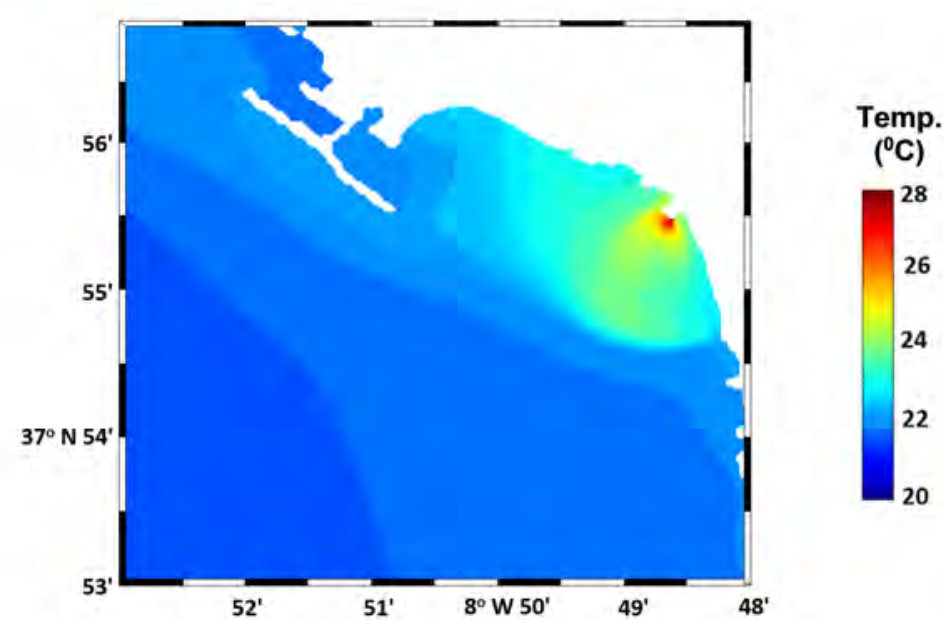

(b)

Figure 5 - Model results for surface temperature, without (a) and with (b) discharge, in south wind scenario.

Figura 5 - Resultados para a temperatura à superfície, sem (a) e com descarga (b), no cenário de vento sul.

an increase of temperature ranging from 2 to $10^{\circ} \mathrm{C}$ (Figure 6), relatively to the reference scenario, and the effect on surface temperature is noticed up to a maximum distance of approximately $2 \mathrm{~km}$ from the outlet. In south wind scenario, with wind intensity about $4 \mathrm{~m} / \mathrm{s}$, a thermal plume is also noticeable at surface (Figure 7). There is an increase of temperature varying between 2 and $10^{\circ} \mathrm{C}$ (Figure 7) in a maximum distance around $2 \mathrm{~km}$ from the outlet, as in the north wind scenario.

These values are generally comparable to values found by other studies for both the temperate anomaly (Lardicci et al., 1999; Chuang et al., 2009; Arieli et al., 2011; Madden et al., 2013) and extent of influence (Arieli et al. 2011). While in the north wind scenario the plume extends longer along the coast, under the south wind scenario the plume extends and impacts a wider area around the outlet.

Tide also plays a significant role on the dispersion of the thermal plume. As observed in Figure 6 and 7, the extent of the plume is higher in ebb or low-tide conditions. Inversely, the plume is more compressed and closer to the coast in flood and high-tide conditions. Results suggest that ebb conditions facilitate the dispersions of the thermal effluent, while flood keeps the warmer waters closer to the outlet.

In both scenarios the thermal plume develops along the direction of the dominant wind incidence. When the south wind is dominant the thermal plume is pushed northward, and finds the coastline, a physical barrier that confines the plume, as seen in Figure 6. In these conditions the thermal plume develops toward the water intake, and the process can be further aggravated during flood and high-tide conditions. This means that a feedback process may occur, by which the water used in the cooling process is continuously drawn at increasing temperatures and, consequently, so is the discharged effluent.

Therefore south wind conditions are the less favorable for the thermal power plant efficiency, although this regime occurs with low probability for this area. This is particularly relevant since the availability of cooling water for steam condensation is a major criterion in the location of power plants.

The release of a warmer mass of water at the coast line, and associated increase in the surface temperature field leads to the vertical thermal stratification. This effect could be reduced with a discharge system that induces mixing like a multiport diffuser system (Kim \& Cho, 2006). In this case the vertical thermal stratification is shown in Figures 8 and 9 (corresponding to the line represented in Figures $4 \mathrm{a}$ and 5a), for north and south winds, respectively. In the reference scenario a wellmixed water column is visible, with colder waters flowing upward, as opposed to the simulations featuring the effluent, where an increase in temperature is visible over the whole water column in the vicinity of the outlet. North wind conditions induces greater initial mix in the effluent discharge, when compared to the south wind scenario. This can be explained by higher wind intensity (north wind) that promotes a stronger mixing of the water column situation, and by the associated upwelling that brings colder and deeper water to the surface.

The thermal signature is stronger at the surface because of the lower density of the warmer that leads to higher buoyancy, and becomes less evident with increasing distance from the shore. Similar observations have been reported for thermal effluents (Arieli et al., 2011), but in this particular situation the intense hydrodynamic regime of the coastal area prevents the enhancemtn of 

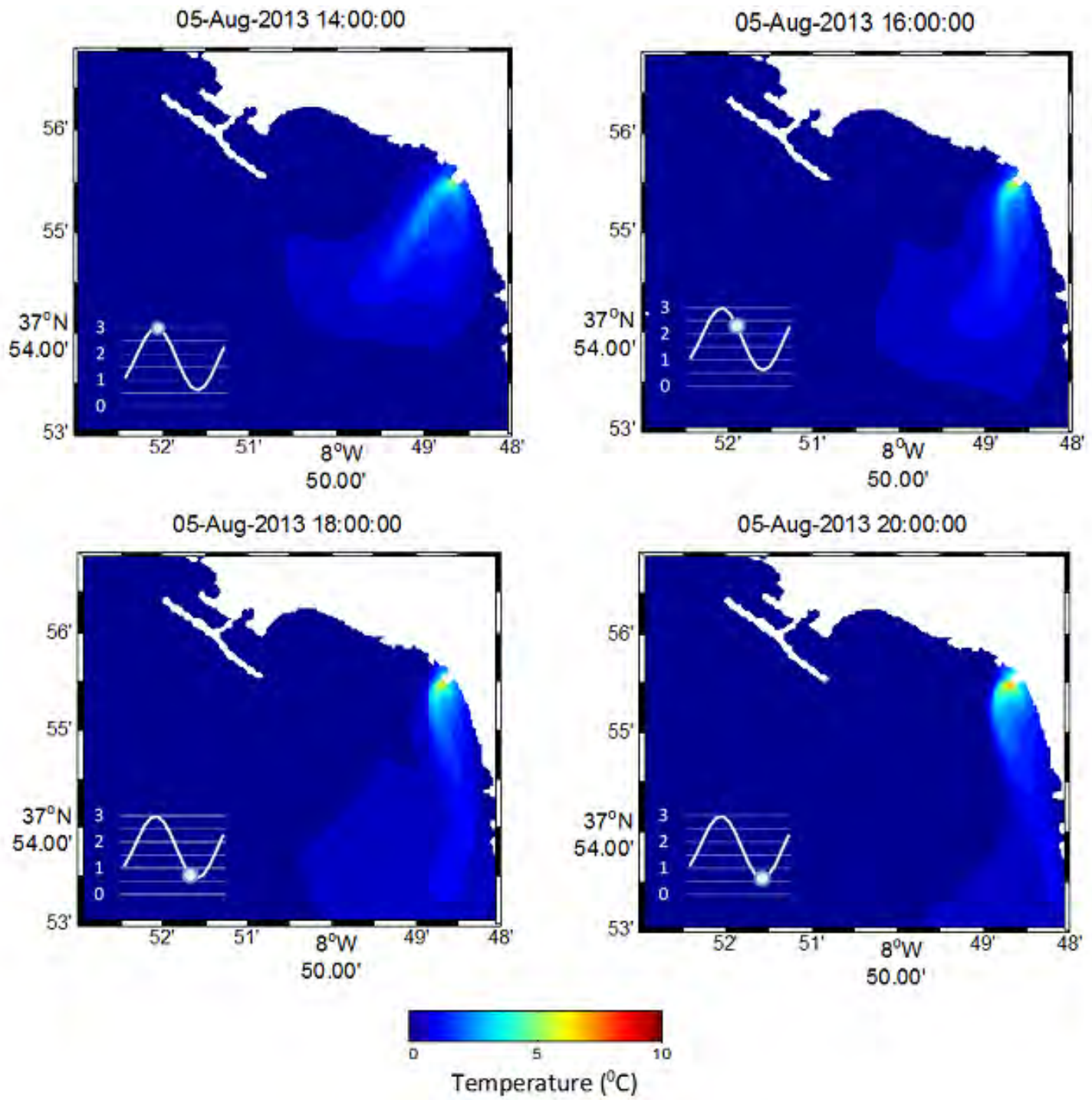

Figure 6 - Sea surface temperature anomaly induced by the presence of the cooling water discharge in the coastal area, in north wind scenario.

Figura 6 - Efeito da descarga térmica na temperatura superficial do oceano, caso do vento norte.

strong and persistent thermal stratification similar to the one observed in lakes (Eloranta, 1983; Kirillin et al., 2013).

\subsection{The choice of model}

Reported works display different approaches to simulate the effect of thermal plumes on the receiving waters: simple models to account for thermal stratification of the water column (Kirillin et al., 2013), mixed approaches using physical and numerical models (ElGhorab, 2013), schematic studies using 2D (You-liang et al., 2011) or 3D numerical models (You-liang \& Jing, 2011), and Lagrangian coherent structures (Wei et al., 2013).

The Sines power plant is similar to other energy production units with water pumped into the power plant to cool the turbines and then channeled back into the sea, lake or river via an open canal (Klein \& Lichter, 2006;
Ingleton \& McMinn, 2012; Kirillin et al., 2013). In such setting the water discharged at the outlet is similar distinct physical properties (temperature) from the to a discharge from a small river or tributary, having receiving water body. The model of choice in this study (MOHID) has been extenseivelly used to simulate coastal systems with comparable discharges (Vaz et al., 2005, 2007, 2008, 2009a, 2009b, 2014), and our results show that it adequatly models the physical control of wind and tide on the dispersion of the thermal effluent in the coastal area.

Similar modeling approaches have been used to simulate the dispersion of thermal plumes (Kolluru et al. 2003, Bedri et al., 2013), while other rely on models that solve the near field dilution, such as CORMIX (Roberts \& Tian, 2004). However, these models were mainly developed for effluent discharges via submarine outfalls, frequently with multiport diffuser. Since this is 

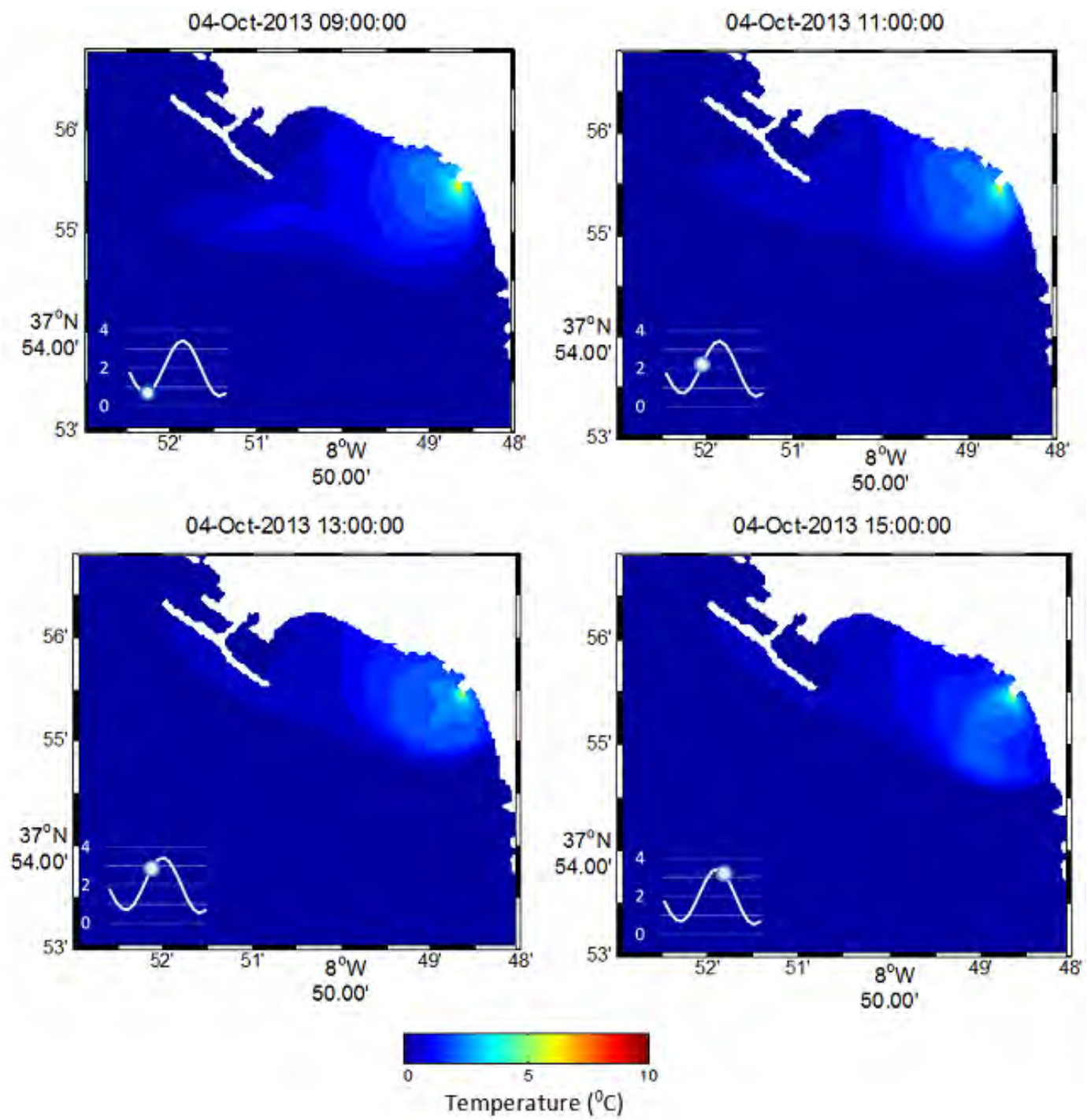

Figure 7 - Sea surface temperature anomaly induced by the presence of the cooling water discharge in the coastal area, in south wind scenario.

Figura 7 - Efeito da descarga térmica na temperatura superficial do oceano, caso do vento sul.

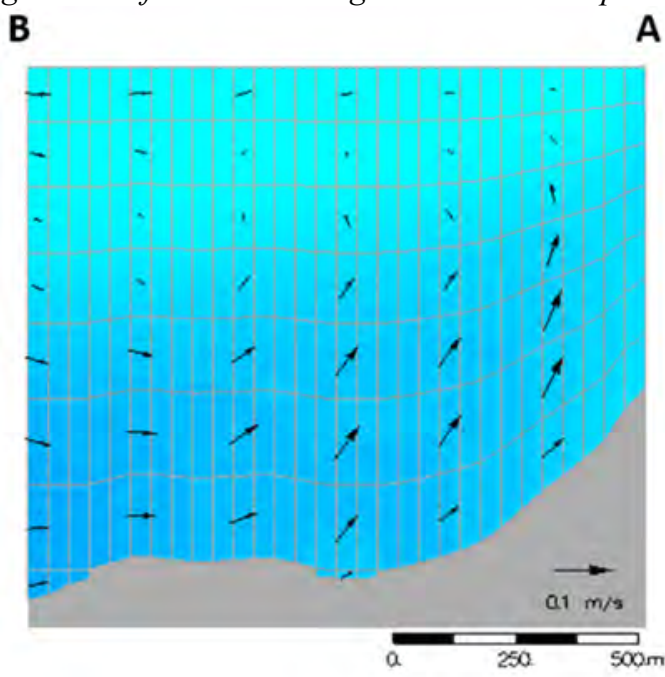

(a)

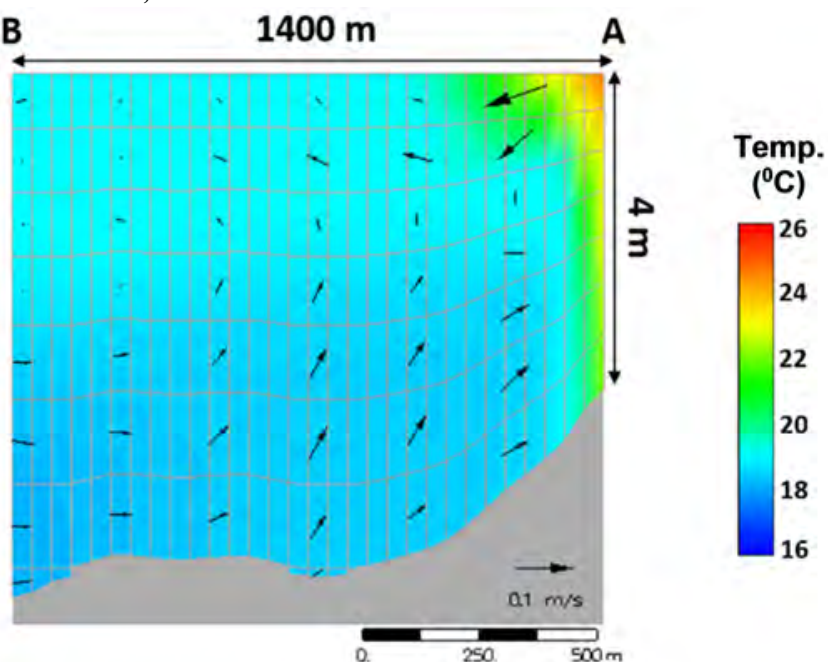

(b)

Figure 8 - Results for temperature profile, without (a) and with (b) discharge, in north wind scenario.

Figura 8 - Resultados para o perfil de temperaturas, sem (a) e com descarga (b), no cenário de vento norte. 
B

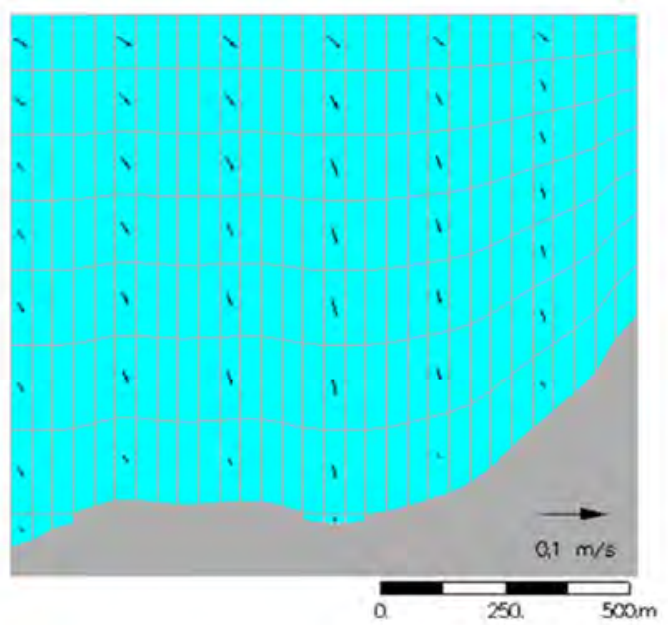

(a)

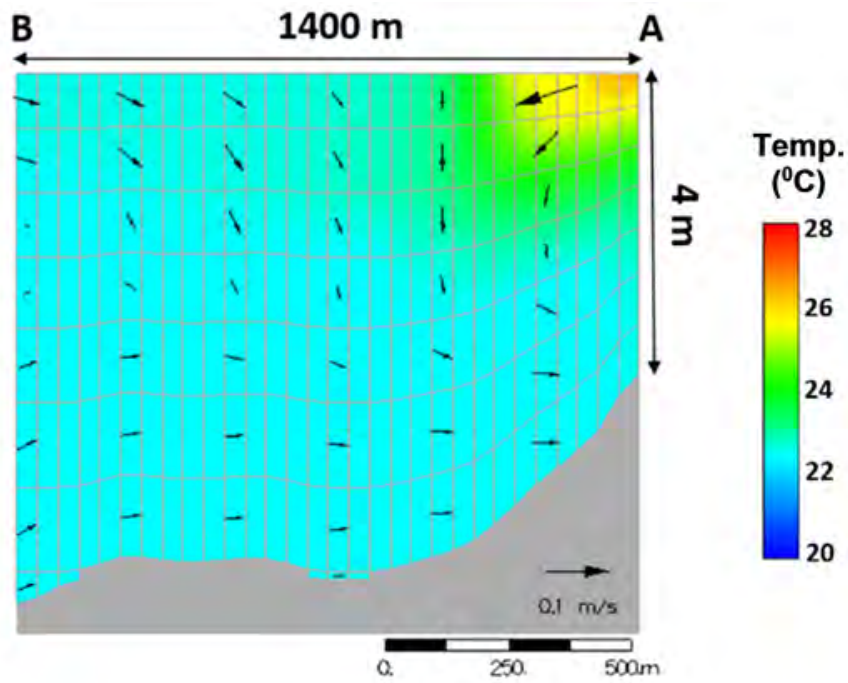

(b)

Figure 9 - Model for temperature profile, without (a) and with (b) discharge, in south wind scenario simulations.

Figura 9 - Resultados para o perfil de temperaturas, sem (a) e com descarga (b), no cenário de vento sul.

not the case with the thermal effluent at Sines, addressing the near field dilution would not necessarily lead to better results. Also, while performing optimally for simple discharges into large basins, in complex ambient environments such as at Sines, CORMIX has been proved to overestimate the dilution, resulting in smaller and cooler modeled plumes than the measured plumes (Schreiner et al., 2002, Roberts \& Tian, 2004).

\section{Concluding remarks}

Numerical models are essential to assess the potential impact of thermal effluents from power plants on the physical and ecological dynamics of natural systems. As the construction of a new generation of coastal power stations in European countries demands robust standards for thermal discharges to transitional and coastal waters (Wither et al., 2012), the dependency on numerical modeling will increase. Similarly to other studies (e.g., Bedri et al., 2013; Shawky et al., 2013) the present work is of particular relevance for the coastal zone management of the Sines area, by contributing to a better understanding of the thermal effluent impact on coastal dynamics.

Model results allowed for a good representation of the thermal effluent effects on coastal circulation and thermal structure. The main effect of the discharge of the cooling water is the formation of a thermal plume and consequent vertical temperature stratification. Model simulations show that wind direction and tide play a significant role on the dispersion of the plume and, consequently, of the surface temperature anomaly induced by the thermal discharge. A well-mixed and elongated plume is observed under north wind dominance, as opposed to a constrained wider plume during south wind conditions.
The worst case scenario, regarding the thermal plume extents, is the south condition. This scenario possibly carries major efficiency losses for the operation of the power plant, since the water at the intake is continuously warming

\section{Appendix}

Supporting Information associated with this article is available online at http://www.aprh.pt/rgci/pdf/rgci-577_Salgueiro_SupportingInformation.pdf

\section{References}

Abbaspour, M.; Javid, A.H.; Moghimi, P.; Kayhan, K. (2005) Modelling of thermal pollution in coastal area and its economical and environmental assessment. International Journal of Environmental Science \& Technology, 2(1):13-26. DOI: 10.1007/BF03325853

Abdel-Latif, M.; Kotb, O. (2010) - Investigating the Environmental Impact of Power Plant Intakes and Outfalls under Tidal Influence (Case Study: Suez Gulf-Egypt). Nile Basin Water Science \& Engineering Journal, 3(2):52-63. Available on-line at http://www.nilebasin-journal.com/PDFFiles/5.pdf

Agarwal, S.K. (2005) - Thermal pollution. In: S. K. Agarwal, Water Pollution, pp.127-136, APH Publishing Corporation, New Delhi, India. ISBN: 9788176488327.

Arieli, R.N.; Almogi-Labin, A., Abramovich, S.; Herut, B. (2011) The effect of thermal pollution on benthic foraminiferal assemblages in the Mediterranean shoreface adjacent to Hadera power plant (Israel). Marine Pollution Bulletin, 62(5):1002-1012. DOI: 10.1016/j.marpolbul.2011.02.036

Ascione, K.I.; Campuzano, F.; Franz, G.; Fernandes, R.; Viegas, C.; Sobrinho, J.; De Pablo, H.; Amaral, A.; Pinto, L.; Mateus, M.; Neves, R. (2014) - Advances in modeling of water quality in estuaries. In: C.W. Finkl \& C. Makowski (eds), Advances in Coastal abd Marine Resources: Remote Sensing and Modeling. Advances in Coastal and Marine Resources. Part II, pp. 237276, Springer International Publishing, Switzerland. ISBN: 9783319063256. DOI: 10.1007/978-3-319-06326-3 10 
Barton, E.D. (2001) - Canary and Portugal currents. In: Steele, J.H.; Thorpe, S.A.; Turekian, K.K. (eds.). Encyclopedia of Ocean Sciences, pp.380-389, Academic Press. DOI: 10.1006/rwos.2001.0360

Bedri, Z.; Bruen, M.; Dowley, A.; Masterson, B. (2013) - Environmental consequences of a power plant shut-down: A threedimensional water quality model of Dublin Bay. Marine Pollution Bulletin, 71(1):117-128. DOI: 10.1016/j.marpolbul.2013.03.025.

Canuto, V.M.V.; Howard, A.; Cheng, Y.; Dubovikov, M.S.M. (2001) - Ocean Turbulence. Part I: One-Point Closure ModelMomentum and Heat Vertical Diffusivities, Journal of Physical Oceonagraphy, 31(6):1413-1426. DOI: $10.1175 / 1520$ 0485(2001)031<1413:OTPIOP>2.0.CO;2

Chippada, S.; Dawson, C.N.; Martinez-Canales, M.L.; Wheeler, M. F. (1998) - Finite element approximations to the system of shallow water equations, Part II: Discrete-time a priori error estimates. SIAM journal on numerical analysis, 36(1):226-250. DOI: $10.1137 / \mathrm{S} 0036142995296515$

Choi, K.H.; Kim, Y.O.; Lee, J.B.; Wang, S.Y.; Lee, M.W.; Lee, P.G.; Ahn, D.S.; Hong, J.S.; Soh, H.Y. (2012) - Thermal impacts of a coal power plant on the plankton in an open coastal water environment. Journal of Marine Science and Technology (ISSN: 1023-2796), 20(2):187-194, National Taiwan Ocean University, Keelung, Taiwan. Available on-line at http://jmst.ntou.edu.tw/marine/20-2/187-194.pdf

Chuang, Y.L.; Yang, H.H.; Lin, H.J. (2009) - Effects of a thermal discharge from a nuclear power plant on phytoplankton and periphyton in subtropical coastal waters. Journal of Sea Research, 61(4):197-205. DOI: 10.1016/j.seares.2009.01.001

Coulter, D.P.; Sepúlveda, M.S.; Troy, C.D.; Höök, T.O. (2014) Thermal habitat quality of aquatic organisms near power plant discharges: potential exacerbating effects of climate warming Fisheries. Management and Ecology, 21(3):196-210. DOI: 10.1111/fme.12064

de Pablo, H.; Brito, D.; Mateus, M.; Trancoso, A.R.; Campuzano, F.J.; Pinto, L.; Neves, R. (2013) - An integration methodology to estimate water fluxes and constituents budgets in coastal areas: application to the Tagus coastal area. In: M. Mateus \& R. Neves (eds.) Ocean modelling for coastal management. Case studies with MOHID, pp 213-224, IST Press, Lisbon, Portugal. ISBN: 978-989-8481-24-5. Available on-line at: http://www.mohid.com/publicdata/products/bookpapers/2013_m ohidbook_c01.pdf

El-Ghorab, E.A.S. (2013) - Physical model to investigate the effect of the thermal discharge on the mixing zone (Case Study: North Giza Power Plant, Egypt). Alexandria Engineering Journal, 52(2):175-185. DOI: 10.1016/j.aej.2012.12.003

Eloranta, P.V. (1983) - Physical and chemical properties of pond waters receiving warm-water effluent from a thermal power plant. Water research 17(2):133-140 DOI: 10.1016/00431354(83) 90092-1

Fiúza, A.F.G. (1983) - Upwelling patterns off Portugal. In: Erwin Suess \& Jörn Thiede, (eds.), Coastal Upwelling its sediment record, pp.85-98, NATO Conference Series Volume 10B, Springer US. ISBN: 9781461566533.

Flather, R. A. (1976) - A tidal model of the northwest European continental shelf. Memoires Societe Royale des Sciences de Liege, 10(6):141-164.

Fossati, M.; Piedra-Cueva, I. (2013) - A 3D hydrodynamic numerical model of the Río de la Plata and Montevideo's coastal zone. Applied Mathematical Modelling, 37(3):1310-1332. DOI: 10.1016/j.apm.2012.04.010
Fossati, M.; Santoro, P.; Urrestarazu, S.; Piedra-Cueva, I. (2011) Numerical study of the effect of a power plant cooling water discharge in the Montevideo Bay. Journal of Applied Mathematics, 2011. DOI: 10.1155/2011/970467

Hester, E.T.; Doyle, M.W. (2011) - Human Impacts to River Temperature and Their Effects on Biological Processes: A Quantitative Synthesis1. Journal of the American Water Resources Association, 47(3):571-587. DOI: $10.1111 / \mathrm{j} .1752-$ 1688.2011.00525. $\mathrm{x}$

Holmes, N. (1970) - Marine fouling in power stations. Marine Pollution Bulletin, 1(7):105-106. DOI: 10.1016/0025326X(70)90217-1

Hunt, C.D.; Mansfield, A.D.; Mickelson, M.J.; Albro, C.S.; Geyer, W.R.; Roberts, P.J. (2010) - Plume tracking and dilution of effluent from the Boston sewage outfall. Marine Environmental $\begin{array}{lll}\text { Research, } & 70(2): 150-161 . & \text { DOI: }\end{array}$ 10.1016/j.marenvres.2010.04.005.

Ingleton, T.; McMinn, A. (2012) - Thermal plume effects: A multidisciplinary approach for assessing effects of thermal pollution on estuaries using benthic diatoms and satellite imagery. Estuarine, Coastal and Shelf Science, 99:132-144. DOI: 10.1016/j.ecss.2011.12.024

Jan, S.; Chen; C. T. A.; Tu, Y. Y.; Tsai, H. S. (2004) - Physical properties of thermal plumes from a nuclear power plant in the southernmost Taiwan. Journal of Marine Science and Technology, 12(5):433-441. Available on-line at http://jmst.ntou.edu.tw/marine/12-5/433-441.pdf

Jiang, Z.; Liao, Y.; Liu, J.; Shou, L.; Chen, Q.; Yan, X.; Zhu, G.; Zeng, J. (2013) - Effects of fish farming on phytoplankton community under the thermal stress caused by a power plant in a eutrophic, semi-enclosed bay: Induce toxic dinoflagellate (Prorocentrum minimum) blooms in cold seasons. Marine Pollution Bulletin, 76(1):315-324. DOI: 10.1016/j.marpolbul.2013.07.006

Jones, G.R.; Nash, J.D.; Doneker, R.L.; Jirka, G.H. (2007) - Buoyant surface discharges into water bodies. I: flow classification and prediction methodology. Journal of Hydraulic Engineering, 133(9):1010-1020. DOI: 10.1061/(ASCE)0733-9429

Kelso, J.R.M.; Milburn, G.S. (1979) - Entrainment and Impingement of Fish by Power Plants in the Great Lakes which use the Once-Through Cooling Process. Journal of Great Lakes Research, 5(2):182-194. DOI: 10.1016/S0380-1330 (79)72145-9

Kim, D.G.; Cho, H.Y. (2006) - Modeling the buoyant flow of heated water discharged from surface and submerged side outfalls in shallow and deep water with a cross flow. Environmental Fluid Mechanics, 6(6):501-518. DOI: 10.1007/s10652-006-9006-3

Kirillin, G., Shatwell, T.; Kasprzak, P. (2013) - Consequences of thermal pollution from a nuclear plant on lake temperature and mixing regime. Journal of Hydrology, 496:47-56. DOI: 10.1016/j.jhydrol.2013.05.023

Klein, M.; Lichter, M. (2006) - Monitoring changes in shoreline position adjacent to the Hadera power station, Israel. Applied Geography, 26(3):210-226. DOI: 10.1016/j.apgeog.2006.01.001

Kolluru, V. S., Buchak, E. M., \& Brinkmann, P. E. (2003) - Hydrodynamic modeling of coastal LNG cooling water discharge. Journal of Energy Engineering, 129(1):16-31. DOI: 10.1061/(ASCE)0733-9402(2003)129:1(16)

Langford, T. (1990) - Heat Disposal and the Sources of Thermal Discharges. In: T. Langford (ed.), Ecological Effects of Thermal Discharges, pp.11-20, Elsevier Applied Science Publishers Ltd., London, UK. ISBN: 9781851664511.

Lardicci, C., Rossi, F.; Maltagliati, F. (1999) - Detection of thermal pollution: variability of benthic communities at two different spatial scales in an area influenced by a coastal power station. Marine Pollution Bulletin, 38(4):296-303. DOI: 10.1016/S0025-326X(98)00149-0 
Lentz, S.J.; Largier, J. (2006) - The Influence of Wind Forcing on the Chesapeake Bay Buoyant Coastal Current. Journal of Physical Oceanography, 36(7):1305-1316. Available on-line at http://journals.ametsoc.org/doi/abs/10.1175/JPO2909.1

Madden, N.; Lewis A.; Davis M (2013) - Thermal effluent from the power sector: an analysis of once-through cooling system impacts on surface water temperature. Environmental Research Letters, 8(3):035006. DOI: 10.1088/1748-9326/8/3/035006

Martinez-Arroyo, A.; Abundes, S.; Gonzalez, M.E.; Rosas, I. (2000) - On the influence of hot-water discharges on phytoplankton communities from a coastal zone of the Gulf of Mexico. Water, Air, and Soil pollution, 119(1):209-230. DOI: $10.1023 / \mathrm{A}: 1005161309609$

Martins, F.; Neves, R.; Leitão, P. (1998) - A three-dimensional hydrodynamic model with generic vertical coordinate. In: V. Babovic \& L.C. Larsen (eds.), Hydroinformatics '98: proceedings of the third International Conference on Hydroinformatics, 98(2):1403-1410, Leiden, The Netherlands. ISBN: 9789054109853. Available on-line at http://sapientia.ualg.pt/bitstream/10400.1/124/1/MARThr.pdf

Martins, F.; Neves, R.; Leitão, P.; Silva, A. (2001) - 3D modelling in the Sado estuary using a new generic coordinate approach. Oceanologica Acta 24:51-62. DOI: 10.1016/S03991784(01)00092-5

Martinsen, E.A.; Engedahl, H. (1987) - Implementation and testing of a lateral boundary scheme as an open boundary condition in a barotropic ocean model. Coastal engineering, 11(5):603-627. DOI: 10.1016/0378-3839(87)90028-7.

Mateus, M.; Neves, R. (2008). Evaluating light and nutrient limitation in the Tagus estuary using a process-oriented ecological model. Journal of Marine Engineering \& Technology, 7(2):4354. DOI: $10.1080 / 20464177.2008 .11020213$

Mateus, M.; Riflet, G.; Chambel, P.; Fernandes, L.; Fernandes, R.; Juliano, M.; Neves, R. (2012) - An operational model for the West Iberian coast: products and services. Ocean Science, 8(4):713-732. DOI: $10.5194 / \mathrm{os}-8-713-2012$.

Miranda, R.; Braunschweig, F.; Leitão, P.; Neves, R.; Martins, F.; Santos, A. (2000) - MOHID 2000, a coastal integrated object oriented model. In: Blain, W. R. \& Brebbia, C. A.(eds.) Hydraulic Engineering Software VIII, pp.393-401, WIT Press Southampton, UK. Available on-line at http://w3.ualg.pt/ fmartins/images/hydrosoft2000_MOHID.pdf

Neves, R. (2013) - The MOHID concept. In: Mateus, M. \& Neves, R. (Eds.) Ocean modelling for coastal management - Case studies with MOHID, pp.1-11, IST Press, Lisboa Portugal. ISBN: 978-9898481245. Available on-line at: http://www.mohid.com/publicdata/products/bookpapers/2013_mohidbo ok_c01.pdf

Otero-Díaz, L.; Pierini, J.O.; Chambel-Leitao, P.; Malhadas, M.; Ribeiro, J.; Chambel-Leitao, J.; Restrepo, J. (2014) - Threedimensional oil spill transport and dispersion at sea by an event of blowout. Dyna, 81(186):42-50. Available on-line at: $\mathrm{http} / / /$ dyna.unalmed.edu.co/es/ediciones/186/articulos/v81n186a05/v81n 186a05.pdf

Poornima, E.H., Rajadurai, M., Rao, V.N.R., Narasimhan, S.V.; Venugopalan, V.P. (2006) - Use of coastal waters as condenser coolant in electric power plants: Impact on phytoplankton and primary productivity. Journal of Thermal Biology, 31(7):556564. DOI: 10.1016/j.jtherbio.2006.05.009

Poornima, E.H.; Rajadurai, M.; Rao, T.S; Anupkumar, B; Rajamohan, R; Narasimhan, S.V.; Venugopalan, V.P. (2005) - Impact of thermal discharge from a tropical coastal power plant on phytoplankton. Journal of Thermal biology, 30(4):307-316. DOI: $10.1016 /$ j.jtherbio.2005.01.004

Riflet, G., (2010) - Downscaling large-scale ocean-basin solutions in coastal tri-dimensional hydrodynamic models. 273p., $\mathrm{PhD}$
Thesis, Instituto Superior Técnico, Universidade Técnica de Lisboa, Lisboa, Portugal. Unpublished. Available on-line at http://www.mohid.com/PublicData/products/Thesis/PhD-griflet2010.pdf

Roberts, P.J.; Tian, X. (2004) - New experimental techniques for validation of marine discharge models. Environmental Model$\begin{array}{llll}\text { ling \& } \quad \text { Software, 19(7):691-699. DOI: } & \text { \& }\end{array}$ 10.1016/j.envsoft.2003.08.005

Santos, F.; Gómez-Gesteira, M.; deCastro, M.; Álvarez, I. (2011) Upwelling along the western coast of the Iberian Peninsula: dependence of trends on fitting strategy. Climate Research, 48(23):213-218. DOI: $10.3354 /$ cr00972

Saravanan, P., Priya, A.M., Sundarakrishnan, B., Venugopalan, V.P., Rao, T.S.; Jayachandran, S. (2008) - Effects of thermal discharge from a nuclear power plant on culturable bacteria at a tropical coastal location in India. Journal of Thermal Biology, 33(7):385-394. DOI: 10.1016/j.jtherbio.2008.06.006

Schreiner, S.P., Krebs, T. A., Strebel, D.E.; Brindley, A. (2002) Testing the CORMIX model using thermal plume data from four Maryland power plants. Environmental Modelling \& Software, 17(3):321-331. DOI: 10.1016/S1364-8152(01)00065-2

Shawky, Y., Nada, A.M.; Abdelhaleem, F.S. (2013) - Environmental and hydraulic design of thermal power plants outfalls "Case study: Banha Thermal Power Plant, Egypt". Ain Shams Engineering Journal, 4(3):333-342. DOI: 10.1016/j.asej.2012.10.008

Sousa, M.C.; Vaz, N.; Alvarez, I.; Gomez-Gesteira, M.; Dias, J. M. (2014) - Influence of the Minho River plume on the Rias Baixas (NW of the Iberian Peninsula). Journal of Marine Systems, 139:248-260. DOI: 10.1016/j.csr.2014.06.004

Stewart, R.J.; Wollheim, W.M.; Ariel, M.; Charles, J.V.; Balazs, F.; Richard, B.L.; Bernice, R. - (2013) - Horizontal cooling towers: riverine ecosystem services and the fate of thermoelectric heat in the contemporary Northeast US. Environmental Research Letters, 8(2):025010. DOI: 10.1088/1748-9326/8/2/025010

Takesue, K.; Tsuruta, A. (1978) - The thermal effects of cooling system of a thermal power plant on photosynthesis of marine phytoplankton. Journal of the Oceanographical Society of Japan, 34(6):295-302. DOI: 10.1007/bf02111177

Vaz N.; Dias J.M. (2014) - Residual currents and transport pathways in the Tagus estuary, Portugal: the role of freshwater discharge and wind. Journal of Coastal Research, SI70:610-615 DOI: 10.2112/Si70-103.1

Vaz, N., Dias, J.M., Leitao, P.; Martins, I. (2005) - Horizontal patterns of water temperature and salinity in an estuarine tidal channel: Ria de Aveiro. Ocean Dynamics, 55(5-6):416-429. DOI: $10.1007 / \mathrm{s} 10236-005-0015-4$

Vaz, N., Dias, J.M.; Leitão, P.C. (2009a). Three-dimensional modelling of a tidal channel: the Espinheiro Channel (Portugal). Continental Shelf Research, 29(1):29-41. DOI: 10.1016/j.csr.2007.12.005

Vaz, N., Leitão, P.; Dias, J.M. (2007). Channel-ocean exchange driven by tides and river flow: Espinheiro Channel (Portugal). Journal of Coastal Research, 50(50):1000-1004.

Vaz, N.; Fernandes, L.; Leitão, P.C.; Dias, J.M.; Neves, R. (2009b) The Tagus estuarine plume induced by wind and river runoff: Winter 2007 case study. Journal of Coastal Research, SI56:1090-1094. Available on-line at http://la.cesam.ua.pt/artigos/JDIAS/VAZ_ET_AL.pdf

Wei, X., Ni, P.; Zhan, H. (2013) - Monitoring cooling water discharge using Lagrangian coherent structures: A case study in Daya Bay, China. Marine Pollution Bulletin, 75(1):105-113. DOI: 10.1016/j.marpolbul.2013.07.056

Wither, A., Bamber, R., Colclough, S., Dyer, K., Elliott, M., Holmes, P.; Turnpenny, A. (2012) - Setting new thermal stan- 
dards for transitional and coastal (TraC) waters. Marine Pollution Bulletin, 64(8):1564-1579. DOI 10.1016/j.marpolbul.2012.05.019

You-liang, C.H.E.N.G.; Jing, H.Q.Z.H. (2011) - Effects of Topography on Diffusion of Thermal Discharge in Power Plant. Procedia Environmental Sciences, 11B:618-623. DOI: 10.1016/j.proenv.2011.12.096

You-liang, C.H.E.N.G.; Qing-zhe, H.A.O.; Li-li, L. (2011) - The Effect of Velocity and Outlet Angle of the Thermal Discharge on Its Diffusion with Basic Flow in Power Plant. Procedia Environmental Sciences, 11B:611-617. DOI: 10.1016/j.proenv.2011.12.095

Young, J.S.; Gibson, C.I. (1973) - Effect of thermal effluent on migrating menhaden. Marine Pollution Bulletin, 4(6):94-96. DOI: 10.1016/0025-326X(73)90392-5

\section{Web resources}

CWOP (2014) - Synop Information for 08541 in Sines Montes Chaos, SE, Portugal. In: Weather Quality Reporter, Citizen Weather Observer Program (CWOP), http://weather.gladstonefamily.net/site/08541
Direcção de Produção Térmica da EDP (2012) - Declaração Ambiental 2012 - Central Termoelétricas de Sines. In: http://www.anossa-energia.edp.pt/pdf/desempenho_ambiental/da_76_2012_ cen_term.pdf

EMODnet, 2014. European Marine Observation and Data Network, 2014. EMODnet Bathymetry Portal. In: http://portal.emodnetbathymetry.eu/download-bathymetry.

Instituto Hidrográfico, 2014a. Instituto Hidrográfico| Previsão de Marés - Portugal. Available at http://www.hidrografico.pt/previsaomares.php

Instituto Hidrográfico, 2014b. Instituto Hidrográfico | Bóias Ondógrafo. Available at http://www.hidrografico.pt/boiasondografo.php 